\title{
Characterization of Vibrio damsela strains isolated from turbot Scophthalmus maximus in Spain
}

\author{
Belén Fouz ${ }^{1}$, Jens L. Larsen ${ }^{2}$, Bent Nielsen ${ }^{2}$, Juan L. Barja ${ }^{1}$, Alicia E. Toranzo ${ }^{1}$ \\ ${ }^{1}$ Departamento de Microbiología y Parasitología, Facultad de Biología, Universidad de Santiago, E-15706 Santiago de \\ Compostela, Spain \\ ${ }^{2}$ Laboratory of Fish Diseases, Department of Veterinary Microbiology, The Royal Veterinary and Agricultural University, \\ 13 Bulowsvej, DK-1870 Frederiksberg C, Denmark
}

\begin{abstract}
During a 3 yr period several epizootics of vibriosis in turbot Scophthalmus maximus occurred in different marine farms located in northwestern Spain. Affected fish showed extensive haemorragic areas around the anus, eyes and mouth, as well as a characteristic accumulation of mucus and reddish fluid in the peritoneal cavity. Strains of Vibrio damsela were isolated from diseased fish, representing, to our knowledge, the first report of this bacterium causing problems in cultured turbot. Isolates were biochemically identical to collection strains isolated from both fish and humans, and exhibited the same pattern of drug-sensitivity. However, antigenic differences occurred among the strains, 4 distinct groups of $V$. damsela being recognized. These serological results were supported by lipopolysaccharide profiles and the outer-membrane protein patterns exhibited by the bacterial isolates. In addition, a high molecular weight plasmid band (approx. 90 to $100 \mathrm{MDa}$ ) was detected in all the turbot isolates and in some of the reference strains. Virulence tests showed that the $V$. damsela isolates were pathogenic for turbot and rainbow trout Oncorhynchus mykiss, the LD so ranging from $1 \times 10^{3}$ to $5 \times 10^{5} \mathrm{~V}$. damsela cells per fish.
\end{abstract}

\section{INTRODUCTION}

The coast of Galicia (northwestern Spain) is an important location for the culture of turbot Scophthalmus maximus, a fish of high commercial value. One of the most important limiting factors in saltwater fish culture is the occurrence of disease outbreaks caused by Vibrio species. Although to date only Vibrio anguillarum (serotypes O1 and O2) (Devesa et al. 1985, Toranzo \& Barja 1990) has been reported as the primary causative organism of turbot vibriosis, there are other members of the genus Vibrio in the estuarine environment that have been implicated in disease problems in mariculture (Lupiani et al. 1989, Toranzo et al. 1990).

Some of the marine vibrios associated with fish infections such as Vibrio vulnificus and $V$. damsela are also considered human pathogens. Within $V$. vulnificus, biotypes I and II have been associated with human infections and fish diseases, respectively (Tison et al. 1982). However, in $V$. damsela pathogenicity for fish still remains to be firmly established. Vibrio damsela is a common marine bacterium associated with wound infections in humans, but only a few reports have documented its isolation from diseased fish, e.g. damselfish, brown shark, lemon shark, yellowtail and seabream. This species has also been isolated from turtle, dolphin, octopus and uninfected fish (Table 1).

We have recently described the isolation of Vibrio damsela from turbot in different marine farms located in north western Spain. The isolates represented the first documentation of vibriosis in turbot caused by $V$. damsela (Fouz et al. 1991).

In this report the biochemical, serological, and virulence characteristics of isolates of Vibrio damsela are compared with those of reference strains. In addition, plasmid content and membrane protein patterns of $V$. damsela isolates were also studied.

\section{MATERIAL AND METHODS}

Development of the disease. A new infectious disease was observed in 2 turbot farms located in the Ría 
Table 1. Vibrio damsela isolations reported to date in different countries

\begin{tabular}{|c|c|c|}
\hline Species & Country & Source \\
\hline \multicolumn{3}{|l|}{ Fishes } \\
\hline \multicolumn{3}{|l|}{ Blacksmith } \\
\hline Chromis punctipinnis & USA & Love et al. (1981) \\
\hline \multicolumn{3}{|l|}{ Brown shark } \\
\hline Carcharhinus plumbeus & USA & Grimes et al. (1984) \\
\hline Undescribed seafish & Senegal & Schandevyl et al. (1984) \\
\hline \multicolumn{3}{|l|}{ Lemon shark } \\
\hline Negaprion brevirostris & USA & Grimes et al. (1985) \\
\hline \multicolumn{3}{|l|}{ Yellow tail } \\
\hline Seriola quinqueradiata & Japan & Sakata et al. (1989) \\
\hline \multicolumn{3}{|l|}{ Seabream } \\
\hline Sparus aurata & Spain & Vera et al. (1991) \\
\hline \multicolumn{3}{|l|}{ Molluscs } \\
\hline \multicolumn{3}{|l|}{ Octopus } \\
\hline Octopus joubini & USA & Hanlon et al. (1984) \\
\hline \multicolumn{3}{|l|}{ Reptiles } \\
\hline \multicolumn{3}{|l|}{ Turtle } \\
\hline Dermochelys coriacea & Austrália & Obendorf et al. (1987) \\
\hline \multicolumn{3}{|l|}{ Mammals } \\
\hline \multicolumn{3}{|l|}{ Dolphin } \\
\hline Tursiopp truncatus & Hawaii, USA & Fujioka et al. (1988) \\
\hline \multicolumn{3}{|l|}{ Humans } \\
\hline Wound pathogen & USA & Love et al. (1981) \\
\hline & & Morris et al. (1982) \\
\hline Fatal wound infection & USA & Clarridge et al. (1985) \\
\hline Necrotizing infection & USA & Coffey et al. (1986) \\
\hline
\end{tabular}

de Arosa (northwestern Spain). In the first one (Farm A) the problem was detected several times between summer 1987 and summer 1989, but only once in the second fish farm (Farm B) (Table 2). Size of the diseased fish ranged from 300 to $1500 \mathrm{~g}$.

No abnormal swimming behaviour was observed in the diseased fish. The first deaths occurred when the water temperature increased suddenly from $18^{\circ} \mathrm{C}$ to $22-24^{\circ} \mathrm{C}$. The mortality was low but continuous during the course of the outbreaks. Although the cumulative fish losses were lower than $5 \%$ of the stock in each epizootic, the disease proved costly because of the size of affected fish.

The most remarkable clinical signs in moribund turbot were abdominal distension and haemorragic areas, especially in the eyes and mouth (including palate and jaws) and around the anus (Fig. 1). These external signs were quite similar to enteric redmouth disease of salmonids produced by Yersinia ruckeri. Internally, an accumulation of mucus and reddish fluid in the peritoneal cavity was observed and, in some cases, the liver was pale and with petechiae.

Bacterial isolation and identification. Samples were taken from the liver, kidney and muscle around the haemorragic eyes of moribund turbot and cultured on tryptic soy agar (Difco) supplemented with $1 \% \mathrm{NaCl}$ (TSA-1) and on thiosulphate citrate bile sucrose (TCBS) agar (Oxoid) for bacterial isolation. Pure cultures of the

Table 2. Vibrio damsela. Origin of the strains used in this study. A and B are 2 turbot farms where the infectious disease occurred

\begin{tabular}{|llll|}
\hline Strain & Host & Farm & Year \\
\hline Spanish isolates & & & \\
RG-91 & Turbot & A & 1987 \\
RG-151 & Turbot & A & 1988 \\
RG-153 & Turbot & A & 1988 \\
RG-191 & Turbot & A & 1988 \\
RG-192 & Turbot & A & 1988 \\
RG-193 & Turbot & A & 1988 \\
RG-214 & Turbot & A & 1989 \\
RM-71 & Turbot & B & 1988 \\
Reference strains & & & \\
ATCC 33539 & Damselfish & & 1981 \\
ATCC 35083 & Brown shark & & 1984 \\
CDC-2227-81 & Humans & & 1981 \\
CDC-1421-81 & Humans & & 1981 \\
\hline
\end{tabular}



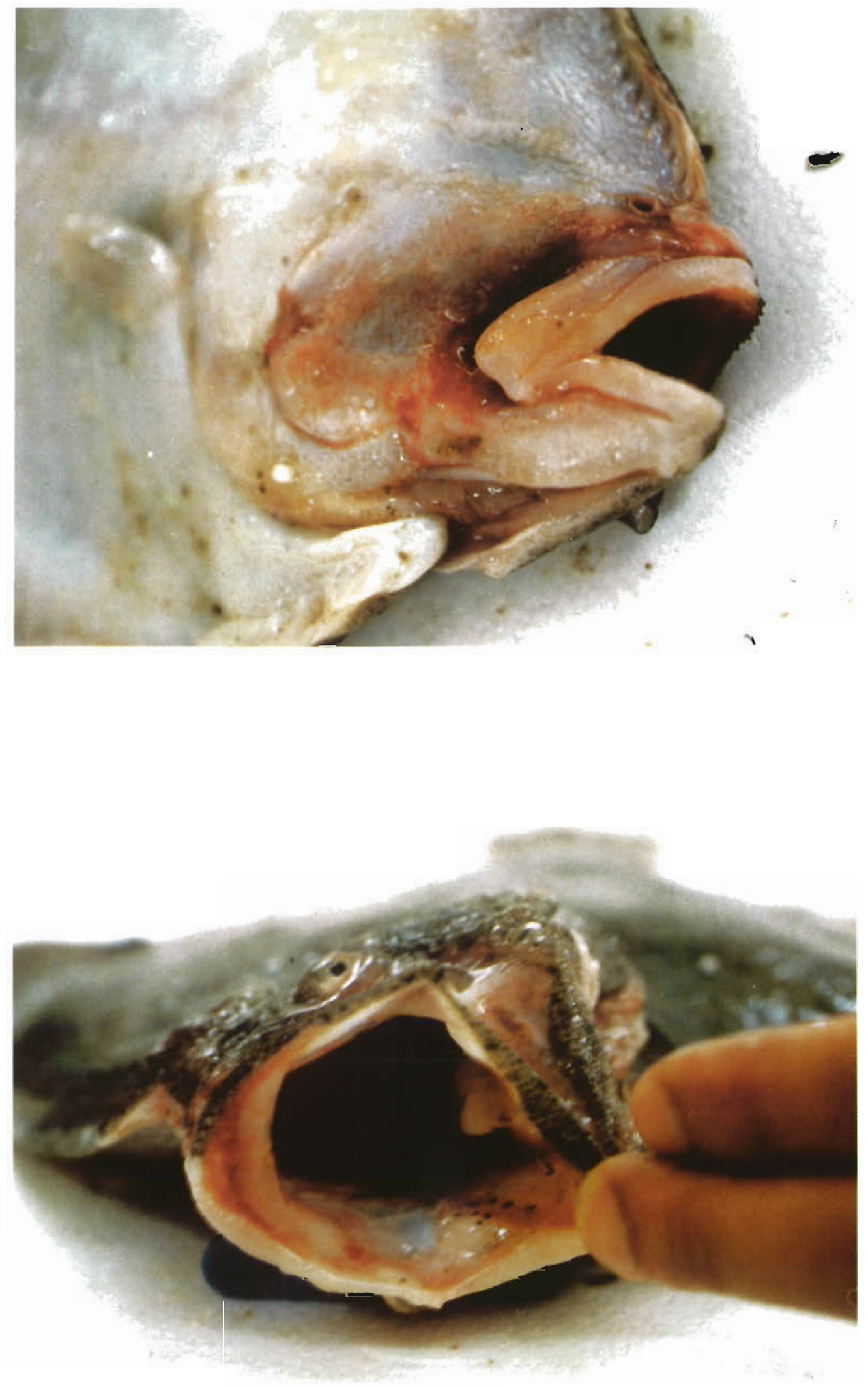

Fig. 1. Scophthalmus maximus. A diseased fish with haemorragic areas around the mouth as well as in the jaws and palate 
isolated bacteria were identified using standard morphological, physiological and biochemical plate and tube tests (West \& Colwell 1984, Fouz et al. 1990). Results were recorded after incubation at $22^{\circ} \mathrm{C}$ for $7 \mathrm{~d}$.

Gram stain, oxidase test, morphology and motility, fermentation of glucose, and sensitivity to the vibriostatic agent $0 / 129$ were used to identify the isolates as members of the genus Vibrio. Biochemical profiles of our isolates were compared with those of virulent strains of $V$. anguillarum isolated from turbot in Spain and with those of reference strains of $V$. damsela isolated from damselfish, brown shark and humans (Table 2).

Representative strains isolated from Farms A and B during the epizontics were maintained in tubes of soft MA (half-strength marine agar) and frozen at $-70^{\circ} \mathrm{C}$ in tryptic soy broth containing $1 \% \mathrm{NaCl}$ and $15 \%(\mathrm{v} / \mathrm{v})$ glycerol for long-term preservation.

Drug sensitivity of the isolates was assayed by the disc diffusion method on Mueller-Hinton Agar (Oxoid) supplemented with $1 \% \mathrm{NaCl}$. The chemotherapeutic agents and their concentrations ( $\mu \mathrm{g} \mathrm{disc}{ }^{-1}$ ) were: penicillin G (10), ampicillin (10), tetracycline (30), chloramphenicol (30), cephalothin (30), novobiocin (5), gentamycin (10), erythromycin (15), kanamycin (30), streptomycin (10), nalidixic acid (30), oxolinic acid (2), furazolidone (300), sulphafurazole (300), and trimethoprim-sulphametoxazole (25).

Serological assays. Source of antigens and antisera: We preparad antisera in rabbits against 6 representative strains of Vibrio damsela ( 3 of our isolates and 3 reference strains). Antisera were obtained as previously described by Sørensen \& Larsen (1986). Briefly, rabbits were injected intravenously with formalinkilled cells twice weekly in consecutive doses of 0.2 , $0.4,0.8$ and $1 \mathrm{ml}\left(10^{9}\right.$ cells ml $\left.{ }^{-1}\right)$. Rabbits were bled from the ear vein 1 wh after the last injection. The blood was allowed to clot and the sera were collected, separated and stored at $-30^{\circ} \mathrm{C}$ until used.

Agglutination tests: To examine the serological relationship among the Vibrio damsela isolates and other related vibrios, slide agglutinations tests were conducted according to the procedures of Sørensen \& Larsen (1986) and Toranzo et al. (1987a). The reactions were performed using the heat-stable ' $O$ ' antigens of each strain. The ' $O$ ' antigens were prepared by heating suspensions of each strain in sodium-acetate buffered saline at $100^{\circ} \mathrm{C}$ for $1 \mathrm{~h}$. A strong and rapid agglutination was recorded as positive and no or only a weak agglutination occurring after 1 to $2 \mathrm{~min}$ as a negative reaction.

In order to determine the existence of possible serogroups within Vibrio damsela isolates, cross-quantitative agglutination tests were performed in microtitre plates using serial 2 -fold dilutions of $25 \mu \mathrm{l}$ aliquots of the antisera. The agglutination titre was considered as the reciprocal of the highest dilution of the antiserum giving a positive reaction after incubation with the antigen overnight at $15^{\circ} \mathrm{C}$.

Virulence test. All our isolates were tested for pathogenicity in rainbow trout ( 5 to $8 \mathrm{~g}$ ) and in turbot $(5 \mathrm{~g})$ at $20^{\circ} \mathrm{C}$ (experimental water temperature). Virulence assays were performed by intraperitoneal inoculation of bacterial doses ranging from $10^{2}$ to $10^{6}$ cells per fish as previously described (Toranzo et al. 1983). Mortalities were recorded daily for a $7 \mathrm{~d}$ period and were considered to be due to the inoculated strain if it was recovered from the internal organs of dead fish in pure culture. The degree of virulence, expressed as the $50 \%$ mean lethal dose $\left(\mathrm{LD}_{50}\right)$, was calculated by the method of Reed \& Müench (1938).

Preparation of LPS and electrophoretic analysis. The preparation of lipopolysaccharides (LPS) was performed by the method of Hitchcock \& Brown (1983). Bacteria were grown in TSA- 1 at $25^{\circ} \mathrm{C}$ for $24 \mathrm{~h}$ and then suspended in $3 \mathrm{ml}$ of PBS to an optical density (O.D.) of 0.8 at $650 \mathrm{~nm}$. Bacterial suspensions $(1.5 \mathrm{ml}$ ) were centrifuged and the resulting cell pellets were resuspended in $50 \mu \mathrm{l}$ of $2 \times$ concentrated sample buffer (0.065 M Tris, pH 6.8, 2\% SDS, $10 \%$ glycerol, $5 \% \beta$ mercaptoethanol, and $0.001 \%$ bromophenol blue) and boiled for $10 \mathrm{~min}$. Ten $\mu \mathrm{l}$ of $2.5 \mathrm{mg} \mathrm{ml}^{-1}$ proteinase $\mathrm{K}$ in $2 \times$ concentrated sample buffer were added and incubated at $60^{\circ} \mathrm{C}$ for $1 \mathrm{~h}$. Samples $(10 \mu \mathrm{l})$ were run in sodium dodecyl sulphate-polyacrylamide gel electrophoresis (SDS-PAGE) (Laemmli 1970) using 12\% acrylamide in the resolving gel and $3 \%$ acrylamide in the stacking gel. The separated LPS components were visualized by the silver staining method described by Tsai \& Frasch (1982).

Immunoblot assays. After SDS-PAGE analysis, separated LPS components were transferred from the gel to $45 \mu \mathrm{m}$ nitrocellulose paper (NCP, Schleicher \& Schuell) according to the procedure described by Towbin et al. (1979). The transblotted NCP sheet was incubated for $1 \mathrm{~h}$ with diluted $(1: 1000)$ rabbit antiserum against whole bacterial cells. LPS components recognized by the antiserum were visualized by reacting the rinsed NCP sheet with goat anti-rabbit IgG alkaline phosphatase conjugate $(1: 3000)$ for $1 \mathrm{~h}$ and the appropriate substrate $\left(0.3 \mathrm{mg} \mathrm{ml}^{-1}\right.$ tetrazolium blue and $0.15 \mathrm{mg}$ $\mathrm{ml}^{-1}$ 5-bromo-4-chloro-3-indolyl phosphate toluidine salt in $0.1 \mathrm{M}$ carbonate buffer, $\mathrm{pH}$ 9.8).

Analysis of cell-envelope proteins. Total and outermembrane proteins were prepared as previously described (Toranzo et al. 1983). The outer membranes were obtained by treatment of the cell envelopes with Sarkosyl $4 \% \mathrm{w} / \mathrm{v}$ in $10 \mathrm{mM}$ Tris- $\mathrm{HCl}(\mathrm{pH} 8.0)$ at room temperature for $20 \mathrm{~min}$ to dissolve the inner membranes. Pellets from total cell envelopes or outer mem- 
branes were examined by SDS-PAGE as described for the LPS analysis.

Analysis of the plasmid content. Extrachromosomal DNA elements in our isolates and in the reference strains were compared. Plasmid DNA was isolated from small volumes $(5 \mathrm{ml})$ of bacterial cultures, following basically the method of Kado \& Liu (1981). DNA samples $(15 \mu \mathrm{l})$ mixed with $5 \mu \mathrm{l}$ of sample buffer $(30 \%$ glycerol, $1 \mathrm{mM}$ EDTA, $0.1 \%$ bromophenol blue [Merck]) were electrophoresed through $0.7 \%$ agarose in Tris-acetate buffer $\left(40 \mathrm{mM}\right.$ Tris, $2 \mathrm{mM} \mathrm{Na}_{2}$-EDTA, adjusted to $\mathrm{pH} 7.9$ with glacial acetic acid) at $100 \mathrm{~V}$ for $2 \mathrm{~h}$ in a horizontal apparatus. Gels were stained in ethidium bromide $\left(0.5 \mu \mathrm{g} \mathrm{ml}^{-1}\right.$ of water $)$, destained in water, and photographed at a wavelength of $254 \mathrm{~nm}$. Plasmids from Escherichia coli 39R 861 (it contained 4 plasmids of $4.6,23.9,42$ and $98 \mathrm{MDa}$ ) and Vibrio anguillarum 775 (it contained the $47 \mathrm{Md}$ plasmid pJM1) were used as reference standards.

\section{RESULTS}

\section{Bacterial identification and characterization}

A Vibrio was obtained in pure culture on TSA-1 and TCBS agar from the internal organs examined (kidney and liver) and from the muscle around the haemorragic eyes of affected turbot.

Preliminary screening showed the bacterial isolates to be Gram-negative motile rods that were relatively pleomorphic and occasionally formed long flexible chains. The additional physiological and biochemical tests listed in Table 3 allowed us to identify the present isolates from turbot as Vibrio damsela because they displayed the same phenotypic profiles as the reference strains from USA.

The strains were oxidase and catalase positive, sensitive to $O / 129$ (both the 10 and $150 \mu \mathrm{g} \mathrm{disc}{ }^{-1}$ ), arginine dihydrolase positive, producers of gas from glucose, and yielded positive Methyl-Red and Voges-Proskauer reactions. They also produced urease but failed to hydrolyze gelatin or to attack sucrose.

The isolates required salt for growth (they grew with 1 to $5 \% \mathrm{NaCl}$ ) and grew over a very wide temperature range (from 15 to $37^{\circ} \mathrm{C}$ ), the latter property helping to explain their pathogenicity for both poikilothermic and homiothermic animals.

The strains of Vibrio damsela shared some biochemical characteristics in common with the species $V$. anguillarum, $V$. ordalii and $V$. vulnificus strains. However, they could readily be differentiated from these species of Vibrio on the basis of their reactions on TCBS-agar and with glucose, sucrose, mannitol, arginine, gelatin and urea (Table 4).
With the chemotherapeutic agents tested, the Vibrio damsela isolates from turbot showed a drug-susceptibility pattern similar to that of the reference strains, all the isolates being resistant to penicillin $G$, ampicillin, erythromycin, streptomycin and sulphafurazol (Table 3).

\section{Serological types and LPS profiles}

The agglutination reactions with thermostable $\mathrm{O}$ antigens (Table 5) revealed that our isolates shared somatic antigens in common with all of the other strains of Vibrio damsela but not with $V$. anguillarum and $V$. ordalii. These results therefore supported the taxonomic findings reported above.

Serological differences among the Vibrio damsela isolates were detected, however, using cross-agglutination tests. The titres of 6 anti- $V$. damsela antisera against each of the $11 \mathrm{~V}$. damsela strains tested are shown in Table 6. Although we found some crossreactions between them, the 11 strains formed basically 4 recognizable groups: strains RG-91, RG-151, RG-153, RG-191, RG-192, RG-193, RG-214 and V. damsela ATCC 33539 (designated as Serogroup A); strain RM71 (Serogroup B); $V$ damsela ATCC 35083 (Serogroup $C$ ) and $V$. damsela CDC-2227-81 (Serogroup D).

Interestingly, the silver-stained LPS profiles of the Vibrio damsela isolates were similar in the 8 strains belonging to the same serological group and distinct for each of the other 4 cultures (Fig. 2a). In addition, the immunoblot assays using antisera from each group supported the serological differences detected by agglutination tests among the strains in that no crossreactions were observed among the distinct serological groups. Fig. $2 \mathrm{~b}$ illustrates this point for the reactions obtained with the antiserum prepared against $V$. damsela ATCC 33539, a Serogroup A strain: only the 8 Serogroup A strains reacted with the antiserum.

\section{Pathogenicity tests}

The virulence assays with Vibrio damsela strains demonstrated that practically all were pathogenic for turbot with an $\mathrm{LD}_{50}$ ranging from $1 \times 10^{3}$ to $3 \times 10^{5} \mathrm{CFU}$ (colony forming units) per fish. Interestingly, rainbow trout proved to be highly susceptible to $V$. damsela under laboratory conditions: LD $_{50}$ 's ranged from $9 \times 10^{3}$ to $1.3 \times 10^{5} \mathrm{CFU}$ per fish. Only $V$. damsela ATCC 35083 (isolated from brown shark) was non-virulent for any of the fish species challenged.

The inoculated strains were reisolated in pure culture from the internal organs of all of the moribund and dead fish. 
Table 3. Comparison of the biochemical and physiological characteristics of the strains isolated from turbot with those of Vibrio damsela reference strains isolated from poikilotherms and homeotherms. +: Positive; $(+)$ : weak positive strain; -: negative; NC: no change, unreactive strain; F: fermentative; G: green colonies; $R$ : resistant; $S$ : sensitive; (S): weak sensitive strain

\begin{tabular}{|c|c|c|c|c|c|c|c|c|c|}
\hline \multirow[t]{2}{*}{ Characteristics } & \multicolumn{5}{|c|}{ Present isolates } & \multicolumn{4}{|c|}{ V. damsela reference strains } \\
\hline & RG-91 & RG-1513 & RG-191 & RG-214 & RM-71 & $\begin{array}{l}\text { ATCC } \\
33539\end{array}$ & $\begin{array}{l}\text { ATCC } \\
35083\end{array}$ & $\begin{array}{c}C D C \\
2227-81\end{array}$ & $\begin{array}{c}C D C \\
1421-81\end{array}$ \\
\hline Luminescence & - & - & - & - & - & - & - & - & - \\
\hline Gram stain & - & - & - & - & - & - & - & - & - \\
\hline Motility & + & + & + & + & + & + & + & + & + \\
\hline Oxidase & + & + & + & + & + & + & + & + & + \\
\hline Catalase & + & + & + & + & + & + & + & + & + \\
\hline Growth on TCBS &,$+ G$ & $+\cdot, G$ &,$+ G$ &,$+ G$ &,$+ G$ &,$+ \mathrm{G}$ &,$+ G$ &,$+ G$ &,$+ G$ \\
\hline \multicolumn{10}{|l|}{ Resistance to: } \\
\hline $0 / 129\left(10 \mu \mathrm{g} \mathrm{disc}^{-1}\right)$ & $\mathrm{S}$ & $\mathrm{S}$ & $\mathrm{S}$ & $\mathrm{S}$ & $\mathrm{S}$ & $\mathrm{S}$ & $\mathrm{S}$ & $\mathrm{S}$ & $\mathrm{S}$ \\
\hline $\mathrm{O} / 129\left(150 \mu \mathrm{g} \operatorname{disc}^{-1}\right)$ & $s$ & $\mathrm{~S}$ & $\mathrm{~S}$ & $\mathrm{~S}$ & $\mathrm{~S}$ & $\mathrm{~S}$ & $\mathrm{~s}$ & $\mathrm{~S}$ & $\mathrm{~S}$ \\
\hline Voges-Proskauer & + & + & + & + & + & + & + & + & + \\
\hline Methyl-Red & + & + & + & + & + & + & + & + & $i$ \\
\hline Indole & - & - & - & - & - & - & - & - & - \\
\hline Moeller's arginine & + & + & + & + & + & + & + & + & + \\
\hline Moeller's lysine & - & - & - & - & - & - & - & $\mathrm{NC}$ & - \\
\hline Moeller's ornithine & - & - & - & - & - & - & - & - & - \\
\hline \multicolumn{10}{|l|}{ Enzyme production: } \\
\hline Gelatinase & - & - & - & - & - & - & - & - & - \\
\hline Urease & + & + & + & + & + & + & + & + & + \\
\hline Caseinase & - & - & - & - & - & - & - & - & - \\
\hline Alginase & - & - & - & - & - & - & - & - & - \\
\hline Chitinase & + & + & + & + & + & $(+)$ & + & $(+)$ & + \\
\hline Amylase & $t$ & + & + & + & + & + & + & + & + \\
\hline Lipase & + & + & + & + & + & + & + & + & + \\
\hline Haemolysis of RBC & + & + & + & + & + & + & + & + & + \\
\hline \multicolumn{10}{|l|}{ Growth in: } \\
\hline $0 \% \mathrm{NaCl}$ & - & - & - & - & - & - & - & - & - \\
\hline $3 \% \mathrm{NaCl}$ & + & + & + & + & + & + & + & + & + \\
\hline $5 \% \mathrm{NaCl}$ & + & + & + & + & + & + & + & + & $(+)$ \\
\hline $8 \% \mathrm{NaCl}$ & - & - & - & - & - & - & - & - & - \\
\hline $10 \% \mathrm{NaCl}$ & - & - & - & - & - & - & - & - & - \\
\hline O/F (Leifson) & $F$ & $\mathrm{~F}$ & $F$ & $\mathrm{~F}$ & $F$ & $\mathrm{~F}$ & F & $\mathrm{F}$ & $\mathrm{F}$ \\
\hline Gas from glucose & + & + & + & + & + & + & + & + & + \\
\hline \multicolumn{10}{|l|}{ Acid production from: } \\
\hline Sucrose & - & - & - & - & - & - & - & - & - \\
\hline Arabinose & - & - & - & - & - & - & - & - & - \\
\hline Glucose & + & + & + & + & + & + & + & + & + \\
\hline Inositol & - & - & - & - & - & - & - & - & - \\
\hline Mannitol & - & - & - & - & - & - & - & - & - \\
\hline Mannose & + & + & + & + & + & + & + & + & + \\
\hline Maltose & + & + & + & + & + & + & + & + & + \\
\hline \multicolumn{10}{|l|}{ Utilization of: } \\
\hline$\gamma$-aminobutyrate & - & - & - & - & - & - & - & - & - \\
\hline L-citrulline & - & - & - & - & - & - & - & - & - \\
\hline Gluconate & & - & - & - & - & - & - & $(+)$ & - \\
\hline Glucuronate & - & - & - & - & - & - & - & - & - \\
\hline Heptanoate & - & - & - & - & - & - & - & - & - \\
\hline$\alpha$-Ketoglutarate & - & - & - & - & - & - & - & - & - \\
\hline Putrescine & - & - & - & - & - & - & - & - & - \\
\hline Tyrosine & - & - & - & - & - & - & - & - & - \\
\hline Xanthine & - & - & - & - & - & - & - & - & - \\
\hline \multicolumn{10}{|l|}{ Growth at: } \\
\hline $4^{\circ} \mathrm{C}$ & - & - & - & - & - & - & - & - & - \\
\hline $15^{\circ} \mathrm{C}$ & + & + & + & + & + & + & + & + & + \\
\hline $22^{\circ} \mathrm{C}$ & + & + & + & + & + & + & + & + & + \\
\hline $37^{\circ} \mathrm{C}$ & + & + & + & + & + & + & + & + & + \\
\hline $44^{\circ} \mathrm{C}$ & - & - & - & - & - & - & - & - & - \\
\hline
\end{tabular}


Table 3 (continued)

\begin{tabular}{|c|c|c|c|c|c|c|c|c|c|}
\hline \multirow[t]{2}{*}{ Characteristics } & \multicolumn{5}{|c|}{ Present isolates } & \multicolumn{4}{|c|}{$V$. damsela reference strains } \\
\hline & RG-91 & RG-1513 & RG-191 & RG-214 & RM-71 & $\begin{array}{l}\text { ATCC } \\
33539\end{array}$ & $\begin{array}{l}\text { ATCC } \\
35083\end{array}$ & $\begin{array}{c}C D C \\
2227-81\end{array}$ & $\begin{array}{c}\text { CDC } \\
1421-81\end{array}$ \\
\hline \multicolumn{10}{|c|}{ Resistance/Sensitivity to: } \\
\hline Penicillin $\mathrm{G}$ & $\mathrm{R}$ & $\mathrm{R}$ & $\mathrm{R}$ & $\mathrm{R}$ & $\mathrm{R}$ & $\mathrm{R}$ & $\mathrm{R}$ & $\mathrm{R}$ & $\mathrm{R}$ \\
\hline Ampicillin & $\mathrm{R}$ & $\mathrm{R}$ & $\mathrm{R}$ & $\mathrm{R}$ & $\mathrm{R}$ & $\mathrm{R}$ & $\mathrm{R}$ & $\mathrm{R}$ & $\mathrm{R}$ \\
\hline Tetracycline & $S$ & $S$ & $S$ & S & $S$ & $\mathrm{~S}$ & $\mathrm{~S}$ & $\mathrm{~S}$ & $S$ \\
\hline Chloramphenicol & $\mathrm{S}$ & $\mathrm{S}$ & $S$ & $\mathrm{~S}$ & $s$ & $\mathrm{~S}$ & $S$ & $S$ & $S$ \\
\hline Cephalothin & $\mathrm{S}$ & $\mathrm{S}$ & $\mathrm{S}$ & $\mathrm{S}$ & S & $\mathrm{S}$ & $\mathrm{S}$ & $\mathrm{S}$ & $\mathrm{S}$ \\
\hline Novobiocin & $S$ & $\mathrm{~S}$ & $S$ & $S$ & $\mathrm{~S}$ & $\mathrm{~S}$ & $\mathrm{~S}$ & $\mathrm{~S}$ & $\mathrm{~S}$ \\
\hline Gentamycin & $\mathrm{S}$ & $\mathrm{S}$ & $\mathrm{S}$ & $\mathrm{S}$ & $\mathrm{S}$ & $\mathrm{S}$ & $\mathrm{S}$ & $\mathrm{S}$ & $\mathrm{S}$ \\
\hline Erythromycin & $\mathrm{R}$ & $\mathrm{R}$ & $\mathrm{R}$ & $\mathrm{R}$ & $\mathrm{R}$ & $\mathrm{R}$ & $\mathrm{R}$ & $\mathrm{R}$ & $\mathrm{R}$ \\
\hline Kanamycin & (S) & (S) & (S) & (S) & $(\mathrm{S})$ & (S) & (S) & (S) & $\mathrm{S}$ \\
\hline Streptomycin & $\mathrm{R}$ & $\mathrm{R}$ & $\mathrm{R}$ & $\mathrm{R}$ & $\mathrm{R}$ & $\mathrm{R}$ & $\mathrm{R}$ & $\mathrm{R}$ & $\mathrm{R}$ \\
\hline Nalidixic acid & $\mathrm{S}$ & $S$ & $\mathrm{~S}$ & $\mathrm{~S}$ & $\mathrm{~S}$ & $\mathrm{~S}$ & $\mathrm{~S}$ & $\mathrm{~S}$ & S \\
\hline Oxolinic acid & $\mathrm{S}$ & $\mathrm{s}$ & $\mathrm{S}$ & $\mathrm{S}$ & $\mathrm{S}$ & $\mathrm{S}$ & $\mathrm{S}$ & $\mathrm{S}$ & S \\
\hline Furazolidone & $\mathrm{S}$ & $\mathrm{S}$ & $\mathrm{S}$ & $\mathrm{S}$ & $\mathrm{S}$ & $\mathrm{S}$ & $\mathrm{S}$ & $\mathrm{S}$ & s \\
\hline Sulphafurazole & $\mathrm{R}$ & $\mathrm{R}$ & $\mathrm{R}$ & $\mathrm{R}$ & $\mathrm{R}$ & $\mathrm{R}$ & $\mathrm{R}$ & $\mathrm{R}$ & $\mathrm{R}$ \\
\hline $\begin{array}{l}\text { Trimethioprim- } \\
\text { sulphamethosazole }\end{array}$ & $\mathrm{S}$ & $\mathrm{s}$ & $s$ & $\mathrm{~S}$ & $S$ & $\hat{\mathrm{S}}$ & $\mathrm{S}$ & $\mathrm{S}$ & $\mathrm{S}$ \\
\hline
\end{tabular}

\section{Analysis of the outer-membrane proteins in Vibrio damsela strains}

Analysis of total cell envelopes as well as outer membranes showed that although all strains exhibited some common protein bands $(40,30,21.5,20.5)$, different patterns were observed (Fig. 3). Ail turbot isolates belonging to Serogroup A (Lanes B to $H$ ) shared at least 5 outer membrane proteins of $70,31.5,30,27.5$ and 26.5 kilodaltons ( $\mathrm{kDa}$ ). Only in the RG-91 strain (Lane B) could we not detect the 72.5 and $89 \mathrm{kDa}$ proteins.

Reference strain ATCC 33539 (Lane I), also belonging to Serogroup A, showed a different pattern. This strain shared another major protein of $33.5 \mathrm{kDa}$ with isolates of Serogroups B and C (Lanes $J$ and K). How- ever, the patterns of Serogroups B and C were more similar to each other than to the pattern of Serogroup A. The human isolates (Lanes $\mathrm{L}$ and $\mathrm{M}$ ) also exhibited distinctive patterns.

\section{Plasmid content of Vibrio damsela strains}

Analysis of the plasmid content of Vibrio damsela strains revealed that all of the isolates from turbot carried a 90 to $100 \mathrm{MDa}$ plasmid band similar in size to that found in the reference strains ATCC 33539 and CDC-2227-81 (Fig. 4). However, no plasmid of similar molecular mass was found in the fish strain ATCC 35083 (Lane $\mathrm{H}$ ) or in the human isolate CDC-1421-81 (Lane K).

Table 4. Vibrio spp. Main differential characteristics among $V$. damsela, V. anguillarum, V. vulnificus and $V$. ordalii. G: Green colonies; Y: yellow colonies; NG: no growth; $V$ : variable

\begin{tabular}{|c|c|c|c|c|}
\hline Characteristics & V. damsela & $V$. anguillarum & $V$ ordalii & $V$. vulnificus \\
\hline Growth on TCBS-agar &,$+ G$ &,$+ Y$ &,$+ Y$ or $N G$ &,$+ G$ \\
\hline Gas from glucose & + & - & - & - \\
\hline \multicolumn{5}{|l|}{ Fermentation of: } \\
\hline Arabinose & - & $\mathrm{V}^{\mathrm{a}}$ & - & - \\
\hline Sucrose & - & + & + & - \\
\hline Mannitol & - & + & - & - \\
\hline Moeller's arginine & + & + & - & - \\
\hline Moeller's lysine & - & - & - & + \\
\hline Moeller's ornithine & - & - & - & V \\
\hline Gelatinase & - & + & + & + \\
\hline Urease & + & - & - & - \\
\hline
\end{tabular}


Table 5. Vibrio spp. Agglutination of thermostable $O$ antigen of selected $V$. damsela strains using rabbit antisera prepared against selected strains of $V$. damsela, $V$. anguillarum and $V$. ordalif. ++ : fast, strong positive reaction; $+:$ positive reaction in 20 to 30 s;

$(+)$ : weak and delayed reaction; -: negative; AG: agglutinating strain

\begin{tabular}{|c|c|c|c|c|c|c|c|c|}
\hline \multirow{3}{*}{ O Antigen } & \multirow[b]{3}{*}{ RG-91 } & \multirow[b]{3}{*}{ RG-191 } & \multicolumn{6}{|c|}{ Antisera to } \\
\hline & & & \multicolumn{2}{|c|}{$V$. damsela } & \multirow[b]{2}{*}{$\begin{array}{l}\text { ATCC } \\
35083\end{array}$} & \multirow[b]{2}{*}{$\begin{array}{c}\text { CDC- } \\
2227-81\end{array}$} & \multirow{2}{*}{$\begin{array}{l}\text { V. anguillarum } \\
\text { R } 82\end{array}$} & \multirow{2}{*}{$\begin{array}{c}\text { V. ordali } \\
\text { NCMB } \\
2167\end{array}$} \\
\hline & & & RM-71 & $\begin{array}{l}\text { ATCC } \\
33539\end{array}$ & & & & \\
\hline RG-91 & ++ & ++ & $(+)$ & ++ & + & $(+)$ & - & - \\
\hline RG-151 & ++ & ++ & $(+)$ & + & $(+)$ & $(+)$ & - & - \\
\hline RG-153 & ++ & ++ & $1+1$ & + & $(+)$ & $(+)$ & - & - \\
\hline RG-191 & ++ & ++ & $(+)$ & + & $(+)$ & $(+)$ & - & - \\
\hline RG-192 & ++ & ++ & $(+)$ & + & $(+)$ & $(+)$ & - & - \\
\hline RG-193 & ++ & $+t$ & $(+)$ & + & $(+)$ & $(+)$ & - & - \\
\hline RG-214 & ++ & ++ & $(+)$ & + & $(+)$ & $1+1$ & - & - \\
\hline$R M-71$ & + & + & ++ & $(+)$ & + & $(+)$ & - & - \\
\hline \multicolumn{9}{|l|}{$V$ damsela } \\
\hline ATCC 33539 & ++ & ++ & $(+)$ & ++ & $1+1$ & + & - & - \\
\hline \multicolumn{9}{|l|}{$V$. damsela } \\
\hline ATCC 35083 & $(+)$ & $(+)$ & $(+)$ & $(+)$ & $+t$ & $(+)$ & - & - \\
\hline \multicolumn{9}{|l|}{$V$. damsela } \\
\hline $\mathrm{CDC}-2227-81$ & + & + & + & + & + & ++ & - & - \\
\hline \multicolumn{9}{|l|}{ V. damsela } \\
\hline CDC-1421-81 & $\mathrm{AG}$ & $\mathrm{AG}$ & $A G$ & $A G$ & $\mathrm{AG}$ & $A G$ & $\mathrm{AG}$ & AG \\
\hline \multicolumn{9}{|l|}{$V$ anguillarum } \\
\hline $\begin{array}{r}\mathrm{R} 82 \\
\end{array}$ & - & - & - & - & - & - & ++ & - \\
\hline \multicolumn{9}{|l|}{$V$. ordalii } \\
\hline
\end{tabular}

\section{DISCUSSION}

Turbot Scophthalmus maximus has been the main fish species cultured on the northwest coast of Spain during the last 5 yr. Perhaps as a result of this, diseases in these intensive culture facilities caused by bacteria, viruses, and parasites have increased, constituting a limiting factor in turbot production. Although until now the most important bacteriological problems were caused by Vibrio anguillarum, other Vibrio species were occasionally implicated in turbot diseases.

We recently reported the first occurrence of vibriosis

Table 6. Vibrio damsela. Cross-agglutination titres among the selected $V$. damsela strains. Rabbit antisera were prepared against whole bacterial cells. Four distinct serogroups are indicated in boxes

\begin{tabular}{|c|c|c|c|c|c|c|}
\hline \multirow[t]{2}{*}{ O Antigen } & \multicolumn{6}{|c|}{ Antisera } \\
\hline & RG-91 & RG-191 & ATCC 33539 & RM-71 & ATCC 35083 & CDC 2227-81 \\
\hline RG-91 & $1280^{\mathrm{a}}$ & 1280 & 640 & $<20$ & $<20$ & $<20$ \\
\hline RG-151 & 640 & 1280 & 640 & $20-40$ & $20-40$ & $20-40$ \\
\hline $\mathrm{RG}-153$ & 640 & 5120 & 640 & $20-40$ & $20-40$ & $20-40$ \\
\hline RG-191 & 640 & 5120 & 640 & $20-40$ & $20-40$ & $20-40$ \\
\hline RG-192 & 640 & 5120 & 640 & $20-40$ & $20-40$ & $20-40$ \\
\hline RG-193 & 640 & 5120 & 640 & $20-40$ & $20-40$ & $20-40$ \\
\hline RG-214 & 640 & 5120 & 640 & $20-40$ & $20-40$ & $20-40$ \\
\hline ATCC 33539 & 1280 & 1280 & 1280 & $<20$ & $<20$ & $<20$ \\
\hline $\mathrm{RM}-71$ & $<20$ & 40 & $<10$ & 160 & 40 & $<20$ \\
\hline ATCC 35083 & $<10$ & $<20$ & $<20$ & 20 & 1280 & $<20$ \\
\hline CDC-2227-81 & 80 & 80 & $20-40$ & $20-40$ & $<10$ & 640 \\
\hline
\end{tabular}



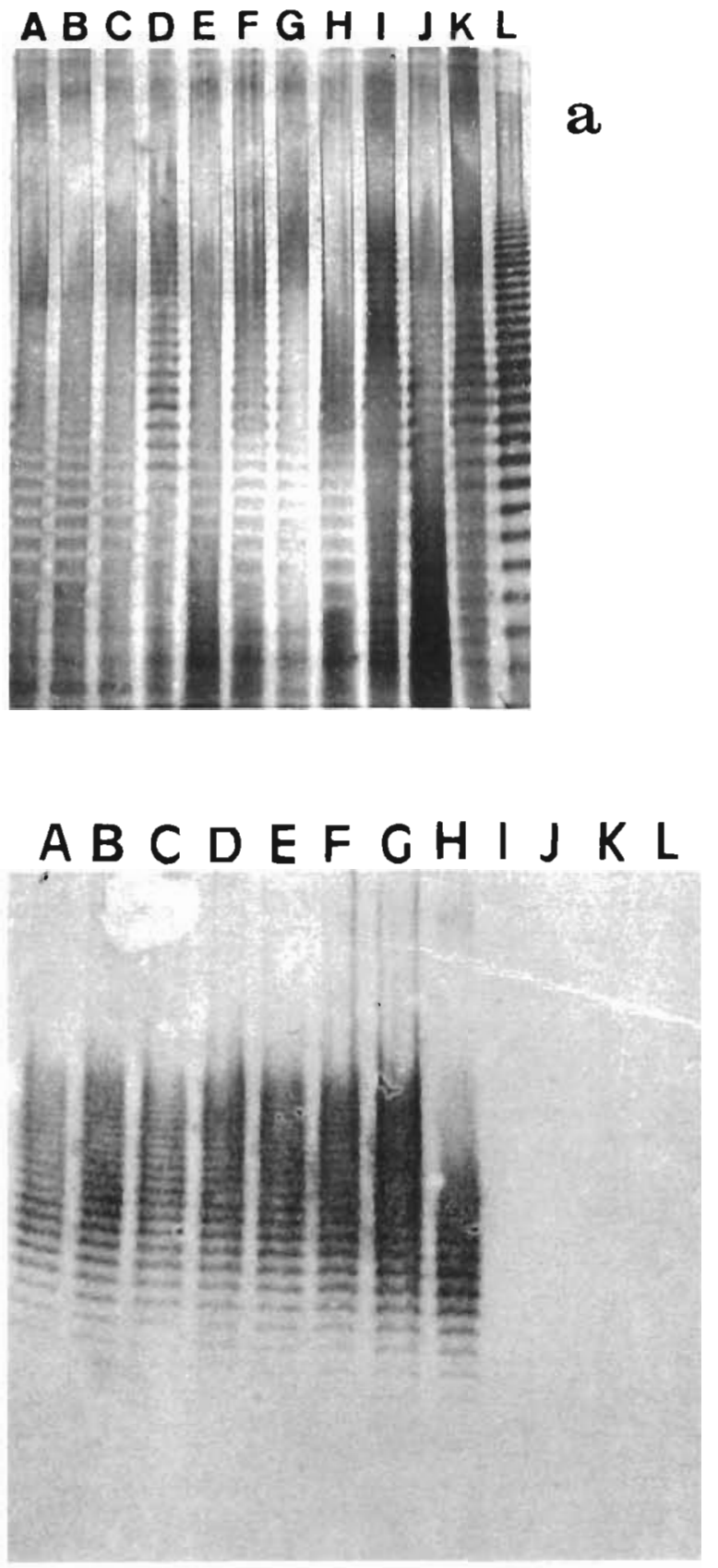

Fig. 2. (a) Silver-stained polyacrylamide gel of isolated lipopolysaccharides of Vibrio damsela strains. (b) Immunoblot assay of $V$. damsela strains using an antiserum prepared against the reference strain ATCC 33539. Lanes: (A) RG-91; (B) RG-191; (C) RG-192; (D) RG-193; (E) RG-194; (F) RG-153; (G) RG-214; (H) ATCC 33539; (I) RM-71; (J) ATCC 35083; (K) CDC-2227-81; (L) CDC-1421-81

caused by Vibrio damsela in 2 turbot farms along the Atlantic coast (Fouz et al. 1991). Interestingly, some of these isolates had been earlier reported to be members of the bacterial group $V$. splendidus- $V$. pelagius
(Lupiani et al. 1989), a group that is very abundant in the aquatic environment (Fouz et al. 1990). However, the taxonomic, serological, and molecular characterization of the turbot isolates indicates that they belong to $V$. damsela species

The biochemical and physiological properties of the present bacterial isolates (Tables $3 \& 4$ ) are similar to those of the reference strains of Vibrio damsela isolated from poikilotherms and homiotherms, giving strong positive reactions for arginine dihydrolase, gas production from glucose, and hydrolysis of urea, and negative reactions for fermentation of sucrose and hydrolysis of gelatin. These features allowed us to differentiate $V$. damsela from other Vibrio species, such as $V$. anguillarum, $V$. ordalii and $V$. vulnificus which are considered to be the main causes of vibriosis in marine aquaculture.

Disease onset was correlated with a sudden increase in water temperature to about 22 to $24^{\circ} \mathrm{C}$. This condition is very favorable for the rapid growth and multiplication of Vibrio damsela, the optimal growth temperature of which under laboratory conditions is approximately the same.

The Vibrio damsela strains isolated from turbot, as well as the reference strains, were sensitive to the chemotherapeutic agents commonly used for controlling vibriosis outbreaks such as tetracycline, oxolinic acid and trimethoprim. No appearance of drug-resistance was observed in the isolates during the course of the disease.

The serological analysis supported the identification of our isolates as Vibrio damsela, because the ' $O$ ' antigens of our isolates reacted positively only with antisera raised against the reference strains of this species (Table 5). However, differences in the strength of the agglutination reactions indicated that the $V$. damsela strains used in this study were not totally homogeneous antigenically. Serological heterogeneity among these $V$. damsela isolates was confirmed by the cross-agglutination tests, which indicated the existence of 4 different Serogroups (A, B, C and D). These data suggest that $V$. damsela, like $V$, anguillarum (Sørensen \& Larsen 1986), is likely to turn out to be a heterogeneous species.

The analysis of lipopolysaccharides (LPS) present in the bacterial cell wall supported the serological heterogeneity detected among the Vibrio damsela strains because all of the isolates belonging to Serogroup $A$ exhibited the same LPS profile, a profile that was different from that of each of the other 3 groups. In addition, the immunoblot assays performed with LPS preparations confirmed these results. Furthermore, although the relationship between the electrophoretic patterns of the outer membrane proteins and the crossagglutination groups was not very strong, the patterns 


\section{A B C D E F G H J K L M}

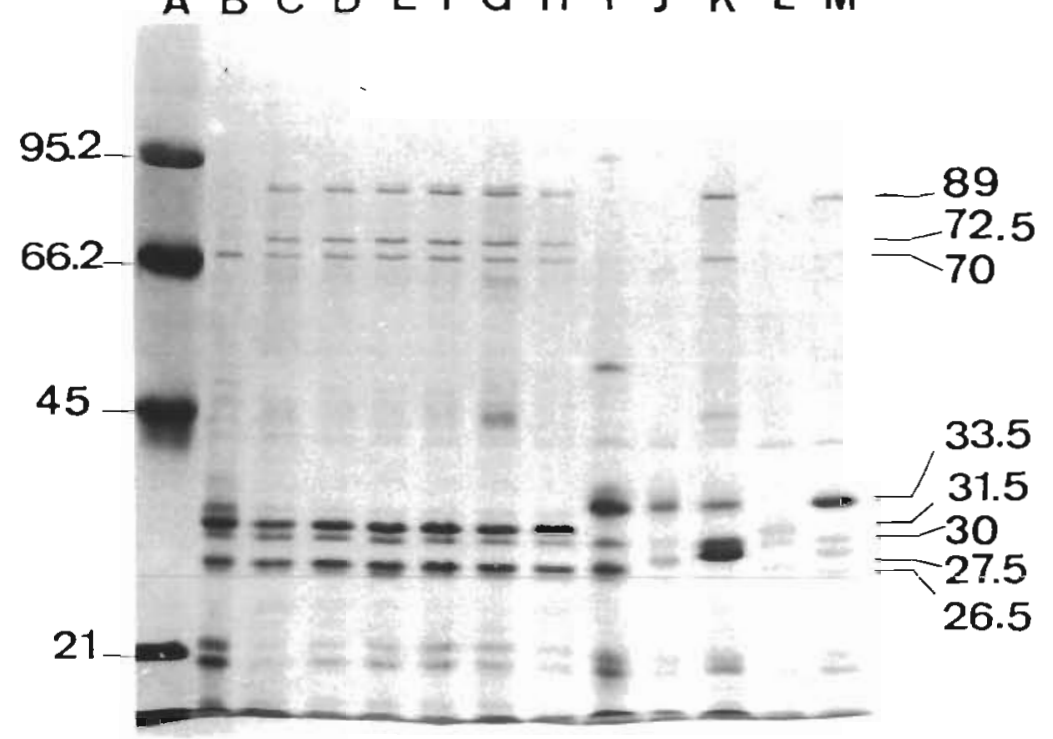

Fig. 3. SDS-PAGE of outer-membrane proteins of selected Vibrio damsela strains: (A) molecular weight standards; (B) RG-91; (C) RG-191; (D) RG-192; (E) RG-193; (F) RG-194; (G) RG-153; (H) RG-214; (I) ATCC 33539; (J) RM-71; (K) ATCC 35083; (L) CDC-2227-81; (M) CDC-1421-81. Numbers indicate molecular weight in kDa

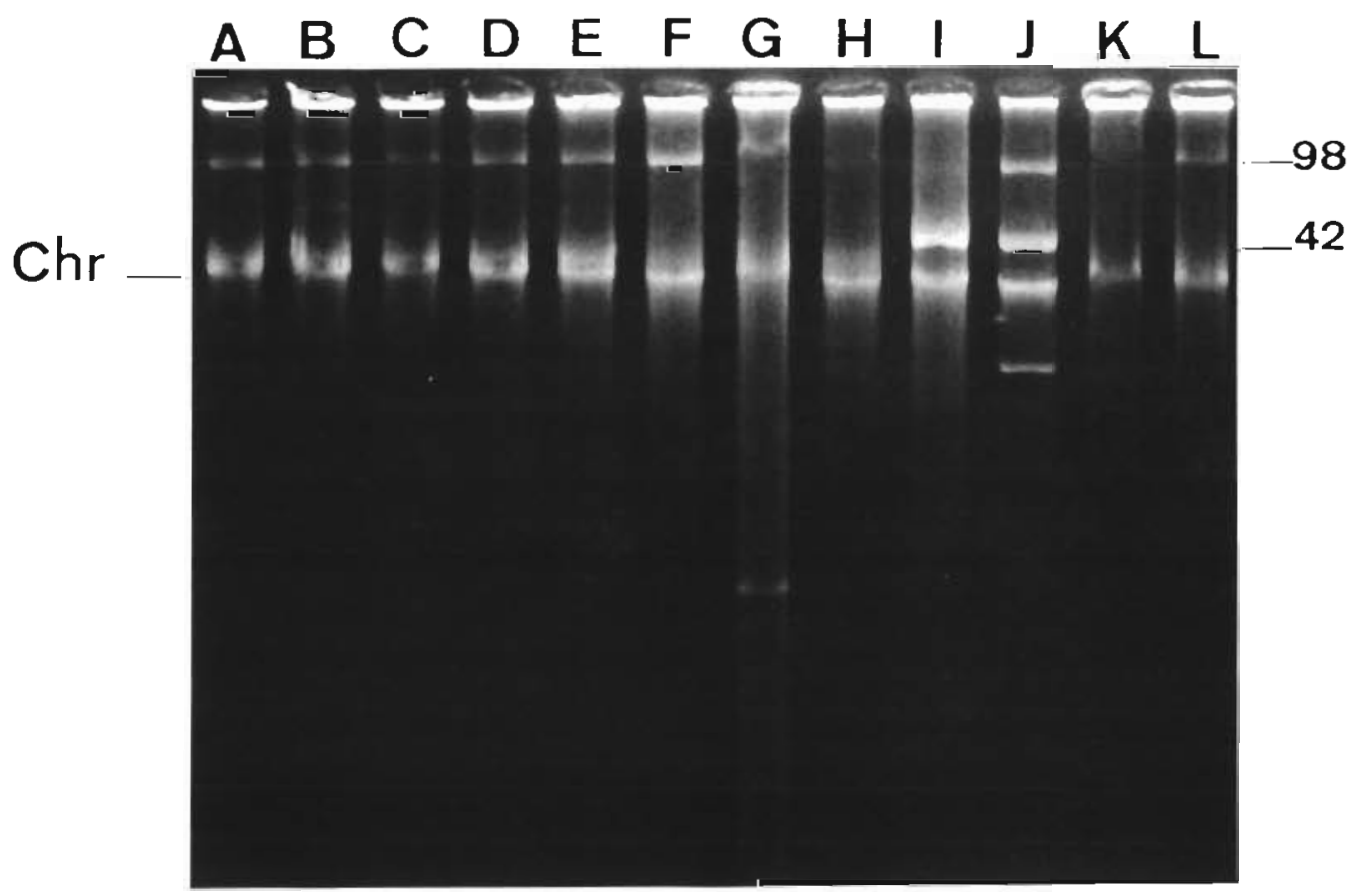

Fig. 4. Demonstration of plasmid profiles in selected strains of Vibrio damsela by the method of Kado \& Liu (1981). Lanes: (A) RG91; (B) RG-191; (C) RG-151; (D) RG-153; (E) RG-214; (F) RM-71; (G) ATCC 33539; (H) ATCC 35083; (I) V. anguillarum 775 (O1); (J) E. coli 39R861; (K) CDC-1421-81; (L) CDC-2227-81 Numbers indicate molecular weight in MDa. Chr: chromosomal band 
tended to support our findings in the agglutination tests. Similar results have been reported by Nomura \& Aoki (1985) and Pyle \& Schill (1985) for several other Gram-negative fish pathogenic bacteria and for $V$. anguillarum by Toranzo et al. (1987b).

All of the turbot isolates harbored a high molecular weight plasmid band ( 90 to $100 \mathrm{MDa}$ ) but it is not known whether the plasmid coded for virulence of the isolates as does the $47 \mathrm{MDa}$ plasmid of $\mathrm{V}$. anguillarum serotype O1 (Crossa 1980, Tolmasky et al. 1985, Toranzo et al. 1987b).

Experimental infections in turbot with our isolates confirmed that the causative agent of these vibriosis outbreaks was Vibrio damsela. Our isolates were also highly pathogenic for rainbow trout, suggesting that $V$. damsela has a host range broader than that observed by Love et al. (1981). Among the reference strains, only ATCC 35083 was not pathogenic for both turbot and rainbow trout. All these features indicate that $V$, damsela does not possess host specificity.

Although Vibrio damsela has been more frequently associated with human wound infections that with fish mortalities, its importance as a pathogen in salt water aquaculture is being increasingly recognized. It seems likely, therefore, that it may become necessary to consider protecting fish against vibriosis with polyvalent vaccines made with strains of $V$. anguillarum serotypes $\mathrm{O} 1$ and $\mathrm{O} 2$ (the main virulent serotypes) and $V$. damsela.

Acknowledgements. B. Fouz thanks the Ministerio de Asuntos Exteriores of Spain and the Danish Education Ministry for a Research fellowship. This study was supported by Grants PB87-1027 and MAR 91-1133-CO2-01 from the Dirección General de Investigación Científica y Técnica (DGICYT), Spain, and Grant no. 65.52 .08 from Nordic Council of Ministers.

\section{LITERATURE CITED}

Clarridge, J. E., Zighelboim-Daum, S. (1985). Isolation and characterization of two haemolytic phenotypes of Vibrio damsela associated with a fatal wound infection. J. clin. Microbiol. 21: 302-306

Coffey, J. A. Jr, Harris, R. L., Rutledge, M. L., Bradshaw, M. W. Williams, T. W. Jr (1986). Vibrio damsela: another potentially virulent marine vibrio. J. infect. Dis. 153: 800-802

Crosa, J. H. (1980). A plasmid associated with virulence in the marine fish pathogen Vibrio anguillarum specifies an ironsequestering system. Nature, Lond. 284: 566-568

Devesa, S., Toranzo, A. E., Barja, J. L. (1985). First report of vibriosis in turbot (Scophthalmus maximus) cultured in northwestern Spain. In: Ellis, A. E. (ed.) Fish and shellfish pathology. Academic Press, London, p. 131-140

Fouz, B., Conchas, R. F., Bolinches, J., Romalde, J. L., Barja, J. L., Toranzo, A. E. (1990). Relationship among pathogenic Vibrio anguillarum and Vibrio tubiashii with environmental vibrios. In: Perkins, F. O., Cheng, T. C. (eds.) Pathology in marine science. Academic Press, New York, p. $77-89$
Fouz, B., Larsen, J. L., Toranzo, A. E. (1991). Vibrio damsela as a pathogenic agent causing mortalities in cultured turbot (Scophthalmus maximus). Bull. Eur. Ass. Fish Pathol. 11. 80-81

Fujioka, R. S., Greco, S. B., Cates, M. B., Schroeder, J. P. (1988). Vibrio damsela from wounds in bottlenose dolphins Tursiops truncatus. Dis. aquat. Org. 4: 1-8

Grimes, D. J., Brayton, P., Colwell, R. R., Gruber, S. H. (1985) Vibrios as authocthonous flora of neritic sharks. Syst. Appl. Microbiol. 6: 221-226

Grimes, D. J., Stemmler, J., Hada, H., May, E. B., Maneval, D., Hetrick, F. M., Tones, R. T., Stoskopf, M., Colwell, R. R. (1984). Vibrio species associated with mortality of sharks held in captivity. Microb. Ecol. 10: 271-282

Hanlon, R. T., Forsythe, J. W., Cooper, K. M., Dinuzzo, A. R., Folse, D. S., Kelly, M. T. (1984). Fatal penetrating skin ulcers in laboratory-reared octopuses. J. invert. Pathol. 44: $67-83$

Hitchcock, P. J., Brown, T. M. (1983), Morphological heterogeneity among Salmonella lipopolysaccharide chemotypes in silver-stained polyacrylamide gels. J. Bacteriol. 154: 269-277

Kado, C. I., Liu, S. $\Upsilon$ (1981). Rapid procedure for detection and isolation of large and small plasmids. J. Bacteriol. 145: $1365-1373$

Laemmli, U. K. (1970). Cleavage of structural proteins during the assembly of the head of the bacteriphage T4. Nature Lond. 227-680-685

Love, M., Fisher, D. T., Hose, J. E., Farmer, J. J., Hickman, F. W., Fanning, G. R. (1981). Vibrio damsela, as a marine bacterium, causes skin ulcers on the damselfisch Chromis punctipinnis. Science 214: 1140-1141

Lupiani, B., Dopazo, C. P., Ledo, A., Fouz, B., Barja, J. L., Toranzo, A. E. (1989). A new syndrome of mixed bacterial and viral etiology in cultured turbot (Scophthalmus maximus). J. aquat. Anim. Hlth 1: 197-204

Morris, J. G. Jr, Wilson, R., Hollis, D. G., Weawer, R. E., Miller, A. G., Tacket, C. O., Hickman, F. W., Blake, P. A. (1982). Illness caused by Vibrio damsela and Vibrio hollisae. Lancet 1: 1294-1297

Nomura, J., Aoki, T (1985). Morphological analysis of lipopolysaccharides from Gram-negative fish pathogenic bacteria. Fish Pathol. 20: 193-197

Obendorf, D. L., Carson, J., McManus, T J (1987). Vibrio damsela infection in a stranded leatherback turtle (Dermochelys coriacea). Wildl. Dis. 23: 666-668

Pyle, S. W., Schill, W. B. (1985). Rapid serological analysis of bacterial lipopolysaccharides by electrotransfer to nitrocellulose. J. Immunol. Methods 85: 371-382

Reed, L. J., Müench, H. (1938). A simple method of estimating fifty percent endpoints. Am. J. Hyg. 27: 493-497

Sakata, T., Matsuura, M., Shimokawa, Y (1989). Characteristics of Vibrio damsela isolated from diseased yellowtail Seriola quinqueradiata. Nippon Suisan Gakkaishi 55: 135-141

Schandevyl, P., VanDyck, E., Piot, P. (1984). Halophilic Vibrio species from seafish in Senegal. Appl environ. Microbiol. 48: $236-238$

Serensen, U. B. S., Larsen, J. L. (1986). Serotyping of Vibrio anguillarum. Appl. environ. Microbiol. 51. 593-597

Tison, D. L., Nishibuchi, M., Greenwood, J. D., Seidler, R. M. (1982). Vibrio vulnificus biogroup 2: new biogroup pathogenic for eels. Appl. environ. Microbiol. 44: 640-646

Tolmaski, M. E., Actis, L. A., Toranzo, A. E., Barja, J. L., Crosa, J. H. (1985). Plasmids mediating iron uptake in Vibrio anguillarum strains isolated from turbot in Spain J. gen. Microbiol. 131. 1989-1997 
Toranzo, A. E., Barja, J. L., Potter, S. A., Colwell, R. R., Hetrick, F. M., Crosa, J. H. (1983). Molecular factors associated with virulence of marine vibrios isolated from striped bass in Chesapeake Bay. Infect. Immun. 39: 1220-1227

Toranzo, A. E., Baya, A. M., Roberson, B. S., Barja, J. L. Grimes, D. J., Hetrick, F. M. (1987a). Specificity of slide agglutination test for detecting bacterial fish pathogens. Aquaculture 61: 81-97

Toranzo, A. E., Santos, Y., Lemos, M. L., Ledo, A., Bolinches, J. (1987b). Homology of Vibrio anguillarum strains causing epizootics in turbot, salmon and trout reared on the Atlantic Coast of Spain. Aquaculture 67: 41-52

Toranzo, A. E., Barja, J. L. (1990). A review of the taxonomy and seroepizootiology of Vibrio anguillarum, with special reference to aquaculture in the northwest of Spain. Dis. aquat. Org. 9: 73-82

Toranzo, A. E., Santos, Y., Bandin, I., Romalde, J. L., Ledo, A.,

Responsible Subject Editor: T. Evelyn, Nanaimo, B.C., Canada
Fouz, B., Barja, J. L. (1990). A five year survey of bacterial fish infections in continental and marine Aquaculture in northwest of Spain. World Aquacult. 21(4): (in press)

Towbin, H., Staehelin, T., Gordon, J. (1979). Electrophoretic transfer of protein from polyacrylamide gels to nitrocellulose sheets: procedure and some applications. Proc. Natl Acad. Sci. U.S.A. 76: 4350-4354

Tsai, C. M., Frasch, C. E. (1982). Staining of lipopoiysaccharides in SDS polyacrylamide gels using silver stainig method. Anal. Biochem. 119: 115-119

Vera, P., Navas, J. I., Fouz, B. (1991). First isolation of Vibrio damsela from seabream (Sparus aurata). Bull. Eur. Ass. Fish Pathol. 11: 112-113

West, P., Colwell, R. R. (1984). Identification and classification of Vibrionaceae. An overview. In: Colwell, R. R. (ed.) Vibrios in the environment. John Wiley \& Sons Inc., New York, p. 285-363

Manuscript first received: March i2, 1991

Revised version accepted: February 13, 1992 